\title{
Various Techniques for Number Plate Recognition- A Review
}

\author{
Anisha Goyal \\ Student \\ University Regional \\ Centre for Information and Management \\ Mohali, Punjab, India
}

\author{
Rekha Bhatia \\ Assistant Professor \\ University Regional Centre \\ For Information and Management \\ Mohali,Punjab,India
}

\begin{abstract}
The number plate reorganization is the system which will recognize the characters from number plates. The techniques of neural networks are applied in the previous techniques to recognize characters from the number plate. In this work, technique will be reviewed which will recognize number plates from a distance and also distorted number plates. The reviewed techniques will be based on morphological, spilt and merge segmentation. In this work, it is analyzed that these techniques perform well in terms of false positive rate.
\end{abstract}

\section{Keywords}

LPR; Optical Character Recognition (OCR); Split and Merge Segmentation; Boundary detection

\section{INTRODUCTION}

As population is increasing traffic on roads is also increasing and with increase in traffic, crime related to it is increasing at greater rate. Various cases of theft, hit and run, robbery, kidnapping, smuggling, on-road fatalities, etc remain unsolved because the vehicle involved could not be recognized accurately as it is not fissile for human eye to verify object or characters from license plate of fast moving vehicles.

This can be achieved by a technique known as Automatic Number Plate Recognition (ANPR) which uses OCR (Optical Character Recognition) to determine the individual character of the number plate. ANPR takes input from LPR (License Plate Recognition) cameras and recognize alpha-numeric character on number plate. It has various applications in toll payments, parking management, road-traffic monitoring, security, crime identification etc [1]. LPR describes specially made CCTV cameras which can deal with challenges associated with capturing license plates in conditions like car speeds, fog, night vision and reflective lens plate material. Each vehicle is uniquely identified from its license plate. An Indian license plate consists of ten characters in order. State code is a set of two alphabets, followed by this is a combination of two digits and alphabets for district information and at last four digit is actual registration number of vehicle. When a number from license plate is correctly recognized, the complete information about vehicle and its owner can be retrieved $[1,3]$.

\subsection{Number Plate Recognition}

It is a technique used to detect vehicle number plate and alpha-numeric characters from number plate itself. Techniques used are:

\subsubsection{Optical Character Recognition (OCR)}

It is electronic conversion of images into machine en-coded text. It is common method of digitizing printed text so that it can be electronically edited, stored more compactly and can be displayed on-line.

\subsubsection{Split and Merge Segmentation}

It attempts to divide an image into uniform region. Partitioning of a digital image into multiple segments is done to simplify or change the representation of an image into something that is more meaningful and is easier to analyze. The image region is split into smaller uniform region until no further splitting can be done and then these smaller regions are again merged to show area of interest.

\subsubsection{Boundary detection}

It is applied to detect the shape of a vehicle and categories it in hatchback, sedan, SUV, Heavy vehicle etc.

\section{RELATED WORK}

Author [1] presents Vehicle Number Plate Detection (VNPD) system algorithm based on template matching. They have devised an efficient method for recognition of Indian vehicle number plates. The algorithm used modified Otsu's method for threshold portioning. The algorithm aims at addressing the problems of scaling and recognition of position of characters.

Author [2] describes Automatic Number Plate Recognition (ANPR) systems which use Optical Character Recognition (OCR) to help determine the individual characters of the number plate. They work on generating key data sets through a simulation process that will generate car number plate images. As a first step, such plates will show variability in character spacing for assessing ANPR systems which will demonstrate the principles for benchmarking. This system avoids the need for carrying out any resource intensive field trials by the Police Force.

Author [3] presents inspection and recognition of Malaysian vehicles using optical character recognition (OCR). An intelligent OCR system has been used as a library and using Lab VIEW software. This system is tested for various implementations to ensure that that proposed method can be applied for real implementation.

Author [4] discusses implementation of a Number Plate Recognition (NPR). This system is designed to replace the current system of manual entry. Vehicle number plate region is extracted using the image segmentation in an image. The resulting data is then used to balance with the records on a database. The system is implemented and simulated in Mat lab, and performance is measured on the real image.

Author [5] develops an accurate and automatic number plate recognition system.

Author [6] discusses about the noisy contain image and applied Adaptive median filter to remove noise from the 
image and gives output as a filtered image. The main purpose of this is to remove noise from the image. For recognition new test has been applied using salt and pepper algorithm for removal of noise with an adaptive median filter.
Author [7] presents the automatic vehicle identification system using vehicle license plate. The OCR method used for recognition is sensitive to misalignment and to different sizes.

\begin{tabular}{|c|c|c|c|}
\hline $\begin{array}{l}\text { AUTHOR NAME } \\
\text { AND YEAR }\end{array}$ & DESCRIPTION & TECHNIQUES USED & OUTCOMES \\
\hline $\begin{array}{l}\text { Hanit Karwal et al. } \\
\text { (IEEE 2015) [1] }\end{array}$ & $\begin{array}{l}\text { The proposed technique shows } \\
\text { the necessity of use of } \\
\text { automated systems to maintain } \\
\text { vehicle information. In the } \\
\text { proposed algorithm an efficient } \\
\text { method for recognition for } \\
\text { Indian vehicle number plate } \\
\text { has been devised. }\end{array}$ & $\begin{array}{l}\text { Paper presents VNPD } \\
\text { system based on template } \\
\text { matching } \\
\text { Normalized with } \\
\text { correlation. } \\
\text { It also uses modified } \\
\text { Otsu's method for } \\
\text { threshold partitioning. }\end{array}$ & $\begin{array}{l}\text { It obtained the accuracy of } 98.07 \\
\% \text {. }\end{array}$ \\
\hline $\begin{array}{l}\text { S. Ramalingam et al. } \\
\text { (IEEE 2014) [2] }\end{array}$ & $\begin{array}{l}\text { In this paper the author has } \\
\text { determined the impact on } \\
\text { ANPR performance caused by } \\
\text { illegal spacing between } \\
\text { characters of number plate. } \\
\text { The causes of inaccurate } \\
\text { ANPR read data are examined } \\
\text { in detail and recommendations } \\
\text { made as to how improvements } \\
\text { could be introduced to } \\
\text { minimize the risk of misreads. }\end{array}$ & $\begin{array}{l}\text { In this key data sets are } \\
\text { generated through a } \\
\text { simulation process that } \\
\text { will generate car number } \\
\text { plate images. In this } \\
\text { Optical Character } \\
\text { Recognition (OCR) is } \\
\text { used. }\end{array}$ & $\begin{array}{l}\text { Variable spacing does appear to } \\
\text { have an adverse impact on } \\
\text { ANPR engines. They were not } \\
\text { able to predict the impact of } \\
\text { illegal spacing or syntax rules } \\
\text { that cause a complete fail to } \\
\text { capture or misreads. Therefore } \\
\text { more work has to b done. }\end{array}$ \\
\hline $\begin{array}{l}\text { Abd Kadir Mahamad } \\
\text { et al. } \\
\text { (SPRINGER 2014) [3] }\end{array}$ & $\begin{array}{l}\text { Automatic inspection and } \\
\text { recognition system has been } \\
\text { proposed for Malaysian } \\
\text { vehicles using optical character } \\
\text { recognition (OCR). } \\
\text { This system is tested for } \\
\text { various implementations to } \\
\text { ensure that that proposed } \\
\text { method can be applied for real } \\
\text { implementation }\end{array}$ & $\begin{array}{l}\text { System is based on } \\
\text { Digital Image Processing } \\
\text { and Optical Character } \\
\text { Recognition (OCR). } \\
\text { An intelligent OCR } \\
\text { Training Interface has } \\
\text { been used as a library and } \\
\text { the system has been } \\
\text { developed using } \\
\text { LabVIEW Software. }\end{array}$ & $\begin{array}{l}\text { The proposed system shows } \\
\text { good performance for inspection } \\
\text { and can recognize an alphabets } \\
\text { and numbers of vehicle Number } \\
\text { plate. }\end{array}$ \\
\hline $\begin{array}{l}\text { Mr.G.T.Sutar et al. } \\
\text { (IJIRSET 2014) [4] }\end{array}$ & $\begin{array}{l}\text { They implement Number Plate } \\
\text { Recognition (NPR). This } \\
\text { system is designed keeping in } \\
\text { mind automation of number } \\
\text { plate detection for the security } \\
\text { reason that could replace the } \\
\text { current system of manual } \\
\text { entry. }\end{array}$ & $\begin{array}{l}\text { In this vehicle number } \\
\text { plate region is extracted } \\
\text { using the image } \\
\text { segmentation in an Image. } \\
\text { Optical Character } \\
\text { Recognition (OCR) } \\
\text { technique is used for } \\
\text { character recognition. }\end{array}$ & $\begin{array}{l}\text { The result shows that the system } \\
\text { works against different } \\
\text { lightening conditions and can be } \\
\text { implemented on the entrance of } \\
\text { a highly restricted areas. System } \\
\text { successfully detects and } \\
\text { recognizes the vehicle number } \\
\text { plate on real images with an } \\
\text { accuracy of } 93 \%\end{array}$ \\
\hline $\begin{array}{l}\text { Kuldeepak et al. } \\
\text { (IJECCT 2012) [5] }\end{array}$ & $\begin{array}{l}\text { They introduced that high } \\
\text { degree of accuracy has been } \\
\text { required by the number plate } \\
\text { recognition when roads are } \\
\text { busy and number of vehicles } \\
\text { are passing through. For this } \\
\text { there is a need of automatic } \\
\text { number plate recognition. It } \\
\text { also gives us warning for the } \\
\text { stolen vehicle which cannot be } \\
\text { possible for man handling } \\
\text { services. }\end{array}$ & $\begin{array}{l}\text { Character segmentation is } \\
\text { used to separate each } \\
\text { image from the } \\
\text { background. } \\
\text { The proposed system has } \\
\text { been implemented using } \\
\text { vision assistant } 8.2 .1 \& \\
\text { labview 11.0. }\end{array}$ & $\begin{array}{l}\text { By optimizing various } \\
\text { parameters, they have achieved } \\
\text { an accuracy of } 98 \% \text {. But for the } \\
\text { tracking stolen vehicles and } \\
\text { monitoring of vehicles an } \\
\text { accuracy of } 100 \% \text { cannot be } \\
\text { compromised with. Therefore to } \\
\text { achieve better accuracy } \\
\text { optimization is required. }\end{array}$ \\
\hline $\begin{array}{l}\text { Quraishi et al. } \\
\text { (RAIT 2012) [6] }\end{array}$ & $\begin{array}{l}\text { The purpose of the author to } \\
\text { present this work is to provide } \\
\text { a new approach for image } \\
\text { recognition using Artificial } \\
\text { Neural Network (ANN). }\end{array}$ & $\begin{array}{l}\text { In this alternative solution } \\
\text { for Object Recognition } \\
\text { using Artificial Neural } \\
\text { Networks (ANN) is used. }\end{array}$ & $\begin{array}{l}\text { If the avg. error is less than } 45 \% \\
\text { ANN can be applied for training } \\
\& \text { testing for the purpose of } \\
\text { recognition. Therefore the test } \\
\text { image is recognized \& matched } \\
\text { successfully with original image. }\end{array}$ \\
\hline
\end{tabular}




\begin{tabular}{|c|c|c|c|}
\hline $\begin{array}{l}\text { Muhammad Tahir } \\
\text { Qadri et.al } \\
\text { (ICETC 2009) [7] }\end{array}$ & $\begin{array}{l}\text { In this the automatic vehicle } \\
\text { identification system using } \\
\text { vehicle license plate is } \\
\text { presented. The system use } \\
\text { series of image processing } \\
\text { techniques of the system for } \\
\text { identifying the vehicle from } \\
\text { the database stored in the PC. }\end{array}$ & $\begin{array}{l}\text { Optical character } \\
\text { recognition (OCR) } \\
\text { technique is used for } \\
\text { character recognition. } \\
\text { The system is } \\
\text { implemented \& simulated } \\
\text { in MATLAB \& } \\
\text { performance is tested on } \\
\text { real images. }\end{array}$ & $\begin{array}{l}\text { There is a need of an } \\
\text { improvement. High resolution } \\
\text { camera can be used to increase } \\
\text { the speed. The OCR method } \\
\text { used is sensitive to misalignment } \\
\text { and to different sizes. }\end{array}$ \\
\hline
\end{tabular}

\section{CONCLUSION}

In this work, various techniques of car number plate recognition are reviewed. The model can be designed based on neural networks which are used to recognize characters from vehicle number plate. This model is based on two main techniques. The first technique is morphological scanning which is used to scan the whole image and extract number plate portion. Second is split and merge segmentation which is used to segment whole detected number plate and then recognize characters with the help of neural network. The proposed model will be capable of detecting number plate from far distance and will also detect the type of vehicle. The model is aimed at solving the problem with higher accuracy and precision.

\section{REFERENCES}

[1] Karwal, Hanit, and Akshay Girdhar, Vehicle NumberPlate Detection System for Indian Vehicles, Computational Intelligence \& Communication Technology (CICT), 2015 IEEE International Conference on. IEEE, 2015.

[2] S. Ramalingam, M. Rhead, and R. Gurney. Impact of character spacing on the performance of Automatic Number Plate Recognition (ANPR) systems through simulation, Security Technology (ICCST), 2014 International Carnahan Conference on. IEEE, 2014.

[3] Mahamad, Abd Kadir, Sharifah Saon, and Sarah Nurul Oyun Abdul Aziz, A Simplified Malaysian Vehicle Plate Number Recognition, Recent Advances on Soft Computing and Data Mining. Springer International Publishing, 2014. 379-388.

[4] Sutar, G. T., and A. V. Shah, Number Plate Recognition Using an Improved Segmentation, International Journal of Innovative Research in Science Engineering and Technology 3 (2014): 12360-12368.
[5] Kuldeepak, Monika Kaushik, and Munish Vashishath, License Plate Recognition System based on Image Processing Using LabVIEW, International Journal of Electronics Communication and Computer Technology (IJECCT) 2.4 (2012).

[6] Quraishi, Md Iqbal, J. Pal Choudhury, and Mallika De, Image recognition and processing using Artificial Neural Network, Recent Advances in Information Technology (RAIT), 2012 1st International Conference on. IEEE, 2012.

[7] Muhammad Tahir Qadir, and Muhammad Asif, Automatic number plate recognition system for vehicle identification using optical character recognition, Education Technology and Computer, 2009. ICETC'09. International Conference on. IEEE, 2009.

[8] Kaur, Er Kavneet, and Vijay Kumar Banga, Number Plate Recognition Using OCR Technique, International Journal of Research in Engineering and Technology 2.09 (2013).

[9] Maeno, Kazuki, et al, Light field distortion feature for transparent object recognition, Proceedings of the IEEE Conference on Computer Vision and Pattern Recognition. 2013.

[10] Zhai, Xiaojun, Faycal Bensaali, and Reza Sotudeh, Realtime optical character recognition on field programmable gate array for automatic number plate recognition system, Circuits, Devices \& Systems, IET 7.6 (2013): 337-344.

[11] Friedrich, Markus, Prokop Jehlicka, and Johannes Schlaich, Automatic number plate recognition for the observance of travel behaviour, Processding of 8 th International Conference on Survey Methods in Transport. 2008.

[12] Kranthi, S., K. Pranathi, and A. Srisaila, Automatic number plate recognition, Int. J. Adv. Tech 2.3 (2011) 408-422. 